\title{
Determinants of social media usage among a sample of rural South African youth
}

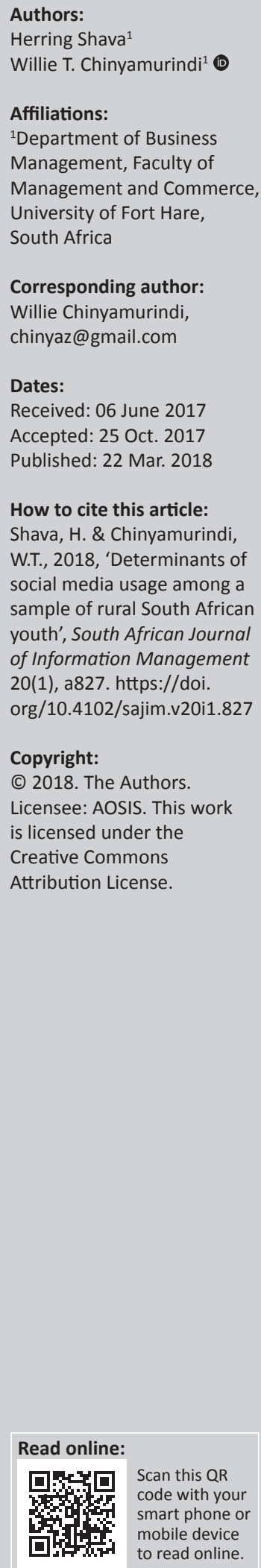

Background: Youths have been found to utilise and adopt information communication technology (ICT) faster than any other population cohort. This has been aided by the advent of social media, especially Facebook and Instagram as platforms of choice. Calls have been made for more research (especially in rural communities) on the usage of ICT platforms such as social media among the youth as a basis for interventions that not only allow for better communication but also for learning.

Objectives: The research investigated the relationship between knowledge sharing, habit and obligation in relation to social media usage among a sample of rural South African youth.

Method: This study is descriptive by design. Primary data were collected from 447 youths domiciled within a rural community in the Eastern Cape Province of South Africa using a selfadministered questionnaire. The respondents to the study were all social media users. A combination of descriptive statistics and Pearson's correlation analysis was used to make meaning of the data.

Results: The study found a significant positive correlation to exist in all three independent variables (knowledge sharing, habit and obligation) with the dependent variable (social media usage) concerning Facebook usage among the sample of South African rural youth.

Conclusion: Based on the findings of the research, recommendations and implications with regard to theory and practice are made.

\section{Introduction}

In 2014, there were at least 1.3 billion Facebook users, 982 million Twitter users and 300 million LinkedIn users worldwide (Smith 2014). Mackey (2016) pointed out that despite the digital divide, the reality in South Africa is that the majority of the youth have access to social media. These websites have become not only a major common channel between friends and relatives but also a new avenue for knowledge sharing ( $\mathrm{Ng} 2016)$. With social media providing direct communication among the youth and being very flexible, the youth are able to share knowledge at alarming rates (Lilley, Grodzinsky \& Gumbus 2012).

Recently, research has begun to examine the use of social media from different dimensions. For example, Kim, Sohn and Choi (2011) found that obtaining social support is a strong motivation for Korean students to use Facebook, while in the United States students were found to place more emphasis on seeking entertainment as a basis for frequenting social media. Thus, the examination of social media motivations and usage across cultures has become an important area of research as presently social media is a worldwide phenomenon.

Facebook remains the most popular social networking site in South Africa, followed by YouTube and Twitter (World Wide Worx 2015). Interestingly, Facebook usage among males and females in South Africa is argued to be equal (World Wide Worx 2015). About 5.6 million males and approximately 5.6 million females use Facebook, thereby giving a total estimate of 11.2 million Facebook users countrywide. In support of the mentioned statistics, BusinessTech (11 September 2015) reported that data published by Facebook South Africa indicated that there are 12 million monthly active Facebook users, with 7.3 million accessing the websites on mobile phones. Other research has also found mobile phone usage to be a popular tool among students to access social media sites (Shava, Chinyamurindi \& Somdyala 2016).

The most striking thing to note is that at least $22 \%$ of the 12 million Facebook users in South Africa are youths aged between 13 and 18 years (BusinessTech 2015). The 21st-century youth, particularly 
those attending college and university, utilise information and information communication technology (ICT) significantly more than earlier generations (World Wide Worx 2015). This research sought to investigate factors that influence a sample of the youth in rural communities to frequent social media, mainly Facebook. Such research within rural communities has been argued as important, given the role that ICT can play in these communities (Chew et al. 2011). Notably, in South African rural communities, we observe scant attention being given to investigating the relationship between knowledge sharing, obligation and habit with social media usage among the youth. Given the calls for more studies exploring an understanding of social media usage among the youth in rural communities (Avis 2015), this study occupies not only a theoretical but also developmental value, given the importance placed on ICT for improving livelihoods (Chinyamurindi \& Louw 2010).

Based on all this, a general research question was proposed: What is the relationship between knowledge sharing, obligation and habit with social media usage among a sample of rural South African youth?

The structure of the rest of this article comprises a literature review based on the independent and dependent variables; the research design and methodology; the results of the empirical analysis; and finally, conclusions as well as recommendations for theory and practice.

\section{Literature review}

This section reviews literature focusing on habit, knowledge sharing and obligation in relation to social media use. For this research, social media use refers to Facebook use.

\section{Habitual social media use}

In the past, studies have tried to describe the concept of habitual social media use, which led to the rise of terms such as media addiction, problematic media use and media abuse (e.g. Caplan 2002; Morahan-Martin 2008; Young 1998). Vishwanath (2015) defined habitual Facebook usage as the involuntary use of the social media platform influenced by satisfaction that the user derives from consistent access, use and continuous interaction on Facebook. This line of thinking is also supported by the media attendance perspective that points out that within a stable environment, an individual acquires habit through repeated media consumption (LaRose 2010). The important aspect to pay attention to in the definition of habit is satisfaction. Satisfaction in this context of social media use draws the line between two close patterns of behaviour, namely habit and regular visits or frequent use of a platform.

Further, Vishwanath (2015) argued that a job-seeking graduate might regularly visit an online job site in search of vacancies posted. This indicates that the regular visits of an unemployed graduate to an online platform are determined by habit. An example of habitual social media use could be that of a person who frequently uses the site because he or she does not want to miss out. This behaviour is explained by the uses and gratification theory, which points out why and how individuals decide to use specific media, and the extent of technology usage is determined by the desire to fulfil certain needs (Leung 2007). According to Huang (2014), an individual can derive seven different forms of gratification through social media usage. The first gratification relates to friendship maintenance. Thus, through social media use, the youth are always in touch with their friends and are able to manage and maintain their relationships. Online exchanges are reciprocal in nature, and the youth who are involved in social exchanges can enjoy comments and virtual gifts through social media.

Also, the youth can take advantage of peer attention on social media and make some efforts to invite comments and feedback on personal issues on any topic of interest. Through social media, the youth also enjoy freedom of expression as social media enable them to discuss all issues that affect them socially, politically and economically. Social media also empowers the youth from an information perspective. Thus, the youth who engage in information seeking behaviour are more likely to keep track of current affairs, making them relevant to the society they live in, one way or the other. It can also be argued that social media plays a pivotal role in enabling the youth to create and manage their identities. This is done through trying out various online identities where they have the capacity to demonstrate different personas and later choose the one that suits them. Lastly, the use of social media provides the youth with an avenue through which they can escape the daily problems and worries they face in the real world.

Addiction is an indicator of habit. A study by North, Johnston and Ophoff (2014) found that Facebook is mainly a socialising tool, although a significant number of its users show some signs and symptoms of addiction. According to SouthAfrica.info (2013), the youth in South Africa, particularly those attending college, are addicted to social media. Surprisingly, this addiction to social media is not regarded as a bad thing by the student group. The World Wide Worx and Student Brands (2013) conducted a South African High-Tech survey using a sample of 1435 students. They found that $59 \%$ were addicted to social media with $16 \%$ of these falling in the highly addicted category. Although the youth stated that social media addiction is not necessarily a worrying phenomenon, $45 \%$ claimed that social media and technology are interfering with studies. Kirschner and Karpinski (2010) also found prolonged Facebook usage to be associated with low grades among school going youths. However, research by Kolek and Saunders (2008), as well as Pasek, More and Hargittai (2009), found no relationship between social media usage and academic performance.

Social media addiction is a cause for concern as an addicted individual loses interest in offline activities, thus becoming antisocial. However, there are also positive effects resulting from habitual social media use. For example, some youths enjoy the prestige of being the first to share important information with their peers, and in so doing, they happen to 
share knowledge with those in need. The extant literature supports the claim that people who share knowledge through online platforms believe in the reciprocity leading to continuous use of online facilities (Wasko \& Faraj 2000).

\section{Knowledge sharing and social media use}

The majority of higher education institutions utilise Facebook to transmit knowledge (Ainin et al. 2015). By so doing, higher education institutions have set a stage where learners are not only gaining knowledge but also use the same social media platform to share the gained knowledge with fellow schoolmates. Students share, among other things, assignments, tutorial questions and solutions. In the process, they help each other to engage with the course, thereby benefiting from one another's contribution. This behaviour is well supported by theory, for example, the Social Learning Theory (SLT) by Bandura (1979). According to the SLT, an individual's behaviour is influenced or determined by how they interact with their surroundings. Facebook, therefore, offers the youth a high-interaction platform where they can easily share their learning experiences and maintain relationships with an opportunity to connect further with other people for social and academic-related purposes (DeAndrea et al. 2012). Although the youth benefit a great deal through knowledge sharing, some have gone a step further and now feel obliged to frequent the site, an act they feel they have limited control over.

\section{Obligation and social media use}

The Harvard's Berkman Klein Center for Internet and Society conducted research with focus groups in a survey undertaken by the Pew Research Center (2012). Findings of that survey were that the youth felt obligated to use Facebook. The study explained that this obligation of the youth is because they regard taking part as vital to the whole youth socialising exercise. Not taking part while friends are participating is placed at par with being rude. Therefore, it is relatively true that the youth feel a social burden associated with Facebook, which in this study is being interpreted as an obligation. This thinking is supported by the Social Exchange Theory (Homans 1958). Obligation in social media interaction is influenced by the concept of benefit expectancy or reciprocity (Kankanhalli, Tan \& Wei 2005). Thus, the Social Exchange Theory in relation to social media usage spells out that, on the one hand, users feel obligated to give their attention in return for the attention they have received from their peers on the same platform. On the other hand, the youth anticipate gaining an equal amount of attention from their peers after providing their own. In summary, it can thus be said that while some youth frequent Facebook for knowledge sharing purposes and some have made it a habit, others feel obliged to use it.

\section{Context}

Johnson et al. (2011) undertook a study titled 'Traffic characterisation and internet usage in rural Africa'. The study compared internet usage in rural Zambia (Macha) and rural
South Africa (Dwesa). Johnson et al. (2011) described rural Africa as remote areas where villages are often dispersed over a large area. Thus, the population is sparse. They further pointed out that in rural Africa, there is lack of infrastructure but where it is found, it is either outdated or utilised below capacity. In addition, the majority of residents in rural Africa rely on a weak subsistence economy. Rural infrastructure is described by the Development Monitor (2012) as roads, irrigation, energy, ICT and water and sanitation. Wyche and Baumer (2016) explored the perceptions of Facebook non-users in rural Zambia. They concurred that rural areas in Africa are characterised by lowemployment and poor technical infrastructure which impact negatively on ICT adoption.

South Africa is the richest country in Africa and the situation in some of its rural areas is slightly different, compared with other rural areas found in Africa. South Africa's road and telecommunication networks are almost similar to those of highly industrialised countries (although internet connectivity in South Africa is slow when compared with Western countries). Gwilliam (2011) concurred and pointed out that Burkina Faso, Namibia and South Africa are exceptional countries in Africa who pride themselves in having the most extensive rural road networks relative to their population. Clark (2013) indicated that South Africa has a dual economy and is also characterised by serious inequalities. Geographically and economically, some sectors of the country are developed but some are still developing. In the South African poverty hearings carried out in the year 2008 in Limpopo, Northern and Eastern Cape provinces, the following issues were highlighted as of major concern: the lack of roads, telecommunications and access to health facilities (Development Monitor 2012). Nkosana, Skinner and Goodier (2016) concurred and pointed out that South Africa faces a digital divide when ICT usage in well-developed cosmopolitan centres, for example, Cape Town, Durban, Pretoria and Johannesburg is compared to underdeveloped rural areas.

Power outages in South Africa were not common until the years 2014 and 2015, a problem caused by unmaintained power grids characterised by ageing equipment and constant technical problems (South Africa Press Association 2015). However, since then, electricity distribution seems to have stabilised. As a result, the majority of rural South Africa has access to electricity when compared with the rural African of other countries. In the year 2007, South Africa had the lowest power outage incidence recorded, with a total of 103, compared with Madagascar's 1872 in the year 2005, Malawi's 239 in the year 2006 and Mozambique's 156 in the year 2007 (Development Monitor 2012). Wyche, Schoenebeck and Forte (2013) undertook a study in Kenya with the goal of exploring social media usage in Kenya. Wyche et al. (2013) concurred that Facebook usage is common in economies where computers, smartphones, high-bandwidth internet and electricity are easily accessed. Network coverage and mobile phone ownership in rural South Africa is high; for example, the study conducted in rural South Africa (Keiskammahoek) by Dalvit and Strelitz (2013) found that 91\% of the respondents had access to network coverage. 
The study was undertaken at a university based in the Eastern Cape Province. The targeted respondents were not students of the university per se but the youth who at that moment were participants of the local rugby tournament and spectators. The tournament, of which the university students were also players for various teams, was hosted by the municipality, and local youth teams of both sexes were welcome to take part. The event normally coincided with a certain public holiday, for example, the heritage day. The tournament is well attended, given the lucrative price money for the top three teams, with plenty of opportunities, for the youth with talent to be spotted by professional rugby teams. Besides the pleasure of participating in the sport, it also offers the youth employment opportunities, given the present high rate of unemployment in South Africa.

Access to social media in rural areas particularly in South Africa has never been a problem; Roux and Dalvit (2014) conducted a study in rural South Africa (Keiskammahoek), and found that $76 \%$ of the respondents who did not own a cell phone, the most used tool in accessing social media, had access to one through sharing. A study conducted in India by Steenson and Donner (2009) also found similar results providing evidence of sharing behaviour. Another South African study conducted in rural South Africa by Dalvit and Strelitz (2013) further provides evidence of sharing behaviour. Dalvit and Strelitz (2013) pointed out that sharing of mobile phones enable people to access and utilise advanced features such as multimedia and network-related activities including money-related applications.

\section{Research methodology}

Pragmatism as research method paradigm guided this study. According to Creswell (2014), researchers who adopt pragmatism are driven by the research question. In an attempt to answer the research question, researchers take into consideration intended consequences of the research, that is, they pursue that which can be considered as worthwhile to fully answer the research question. This study followed a descriptive design. Secondary data were obtained from resources such as journals, internet sources and articles to enable the researchers to gain some understanding of the problem at hand. In addition, as in all descriptive studies, primary data were gathered to conclusively answer the research problem and arrive at informed findings (Wiid \& Diggines 2015; Zikmund \& Babin 2010).

\section{Questionnaire and questionnaire administration}

Data for this study were collected through a survey, with a self-administered questionnaire used as the study instrument. The questionnaire was divided into a demographic section dealing with questions regarding age, language and gender of the respondents; and the general sections which contained six items specifically measuring obligation, six items measuring knowledge sharing, four items measuring habit and three items measuring usage. Data were collected by trained field workers. A total of 1200 questionnaires were distributed in and around the university community located in a rural part of the Eastern Cape Province of South Africa. Among those returned, 447 questionnaires were deemed usable as they had been correctly completed with all required information. The general sections contained the study's variables. Table 1 provides a description of the variables and their reliability test.

\section{Sampling}

Purposive sampling was adopted. Field workers approached potential participants to enquire whether or not they were Facebook users. If the person was a Facebook user, their consent was verbally sought to participate in the study. Thus, participants were part of this study willingly. They were fully advised of their rights, including the right to withdraw from the study and to refrain from responding to questions that they perceived as infringing on their right to privacy.

Purposive sampling is mainly used in qualitative studies. However, it was considered satisfactory to adopt the sampling technique in this study for the following reasons:

- Absence of a sampling frame - It was not practically possible to establish the number of youths who are Facebook users within the geographic setting where the research was undertaken, given the scarcity of resources to carry out this task.

- In purposive sampling, the inquirer selects respondents 'for a specific reason' (Lewin 2011:224). Respondents were selected on the basis that they were Facebook users. Table 2 reveals findings of the study regarding age, gender and language of the respondents.

Comparing Facebook users by gender, the study's findings reveal that more females are users of the social media platform than their male counterparts, as represented by $58.2 \%$ and $41.8 \%$, respectively. Table 2 further reveals that the

TABLE 1: Description of variables employed in the survey and their reliability test.

\begin{tabular}{|c|c|c|}
\hline Variable & Description & $\begin{array}{c}\text { Cronbach's } \\
\text { alpha }\end{array}$ \\
\hline Habit & $\begin{array}{l}\text { This sought to measure the extent to which frequent visits } \\
\text { of the youth on Facebook were a result of habit. Four } \\
\text { questionnaire items were measured on a Likert scale } \\
\text { ( } 1 \text { = Strongly disagree; } 2 \text { = Disagree; } 3 \text { = Neutral; } 4 \text { = Agree; } \\
5=\text { Strongly agree). }\end{array}$ & 0.849 \\
\hline $\begin{array}{l}\text { Knowledge } \\
\text { sharing }\end{array}$ & $\begin{array}{l}\text { Determined the extent to which frequent visits of the } \\
\text { youth on Facebook were as a result of knowledge } \\
\text { sharing. Six questionnaire items were measured on a } \\
\text { Likert scale ( } 1=\text { Strongly disagree; } 2=\text { Disagree; } 3= \\
\text { Neutral; } 4=\text { Agree; } 5=\text { Strongly agree). }\end{array}$ & 0.768 \\
\hline Obligation & $\begin{array}{l}\text { This measured the extent to which the frequent visits of } \\
\text { the youth on Facebook were influenced by obligation. Six } \\
\text { questionnaire items were measured on a Likert scale (1= } \\
\text { Strongly disagree; } 2 \text { = Disagree; } 3=\text { Neutral; } 4=\text { Agree; } 5 \\
\text { = Strongly agree). }\end{array}$ & 0.795 \\
\hline Usage & $\begin{array}{l}\text { This measured the extent to which the youth utilised } \\
\text { Facebook. Measures such as total number of friends and } \\
\text { estimated hours that an individual spent on Facebook } \\
\text { were incorporated and summed up to give a continuous } \\
\text { score. Three questionnaire items were measured on a } \\
\text { Likert scale ( } 1=\text { Strongly disagree; } 2=\text { Disagree; } 3= \\
\text { Neutral; } 4=\text { Agree; } 5 \text { = Strongly agree). }\end{array}$ & 0.701 \\
\hline
\end{tabular}


21-25 age group category was the dominant group utilising Facebook, represented by $60.1 \%$, followed by the $25-30$ age group category, whereas the 31 and above age group category was the least represented $(0.9 \%)$. The majority of Facebook users in this sample were Xhosa-speaking (62.1\%). The later results are mainly influenced by geographical location. As this study was undertaken in a Xhosa-dominated province, the findings do not truly reflect the fact that Xhosa-speaking people are better adopters of social media platforms compared with other South African nationalities.

\section{Results and discussion}

Table 3 shows the four questionnaire items that were used to measure the aspect of habitual social media platform usage. The descriptive statistics scores in the 'strongly agree' and 'agree' columns far outweigh scores depicted in the 'strongly disagree' and 'disagree' columns in three of the questionnaire items, excluding item number 2 (I am addicted to social media) of the questionnaire relating to social media addiction.

From the descriptive statistics, one is compelled to conclude that habitual social media consumption behaviour exists among the sample of South African rural youth that were surveyed. The study's findings concur with those of North et al. (2014) who found that the majority of youth utilise their

TABLE 2: Demographics of respondents ( $n=447)$.

\begin{tabular}{lll}
\hline Variable & Category & $\mathbf{\%}$ \\
\hline Gender & Male & 41.80 \\
Age & Female & 58.20 \\
& $17-20$ & 21.50 \\
& $21-25$ & 60.10 \\
& $26-30$ & 17.50 \\
Language & 31 and above & 0.90 \\
& Xhosa & 62.10 \\
& Zulu & 8.70 \\
& English & 15.90 \\
& Afrikaans & 7.20 \\
& Other & 6.10 \\
\hline
\end{tabular}

mobile devices for socialising purposes, with signs of addiction being evident. Such results may be a cause of concern to educators and parents, especially given that there are previous studies that have tried to investigate the relationship between Facebook use and academic performance. A study by Kirschner and Karpinski (2010) found Facebook users with low-average grades dedicating very few hours to school work compared with non-Facebook users. In support of the aforementioned study, Junco (2012) also found that the rate of Facebook consumption significantly contributed to students' lower grades. By contrast, there are studies that have found no relationship between Facebook use and student performance (Kolek \& Saunders 2008; Pasek, More \& Hargittai 2009).

A recent study undertaken in Malaysia, relying on data from 1165 university students, revealed a positive relationship between high social media consumption rates and student performance (Ainin et al. 2015). In South Africa, the majority of the youth are of the view that even though they are, to a certain degree, addicted to social media, it interferes very little with their studies. Given a sample of 1435 South African students, $85 \%$ revealed that social media enhanced their academic performance, $83 \%$ reported that social media had a positive impact on their social lives and $81 \%$ claimed that social media improved their quality of life (SA High-Tech Student 2013, as cited by World Wide Worx 2015). Only 10\% of the 1435 students claimed that social media was a constant problem as it was continuously getting in the way of studies. Another study by the World Wide Worx and Students Brands (2013) reported that students in South Africa strongly believe that social media plays a pivotal role in their academic lives, especially during the examination period.

Results from Table 4 interestingly reveal that the majority of youth believe that they are somehow obliged to use Facebook owing to expectations their friends or the Facebook community have of them. For example, in Row 4, 36.9\% agree that their friends expect them to contribute during interactions, compared with $20.1 \%$ (agree vs. disagree

TABLE 3: Habitual social media usage frequencies $(n=447)$.

\begin{tabular}{|c|c|c|c|c|c|}
\hline Habit & $\begin{array}{l}\text { Strongly } \\
\text { disagree (\%) }\end{array}$ & Disagree (\%) & $\begin{array}{l}\text { Neither agree } \\
\text { nor disagree }(\%)\end{array}$ & Agree (\%) & $\begin{array}{l}\text { Strongly } \\
\text { agree }(\%)\end{array}$ \\
\hline I do not think I am able to limit myself on how I utilise my Facebook. & 9.6 & 20.8 & 17 & 30.2 & 22.4 \\
\hline I am addicted to social media. & 17.7 & 27.1 & 20.8 & 19.2 & 15.2 \\
\hline I must use social media. & 10.5 & 18.3 & 27.3 & 26.4 & 17.4 \\
\hline Using social media has become natural to me. & 8.9 & 13.2 & 26 & 34.7 & 17.2 \\
\hline
\end{tabular}

TABLE 4: Obligation frequencies $(n=447)$.

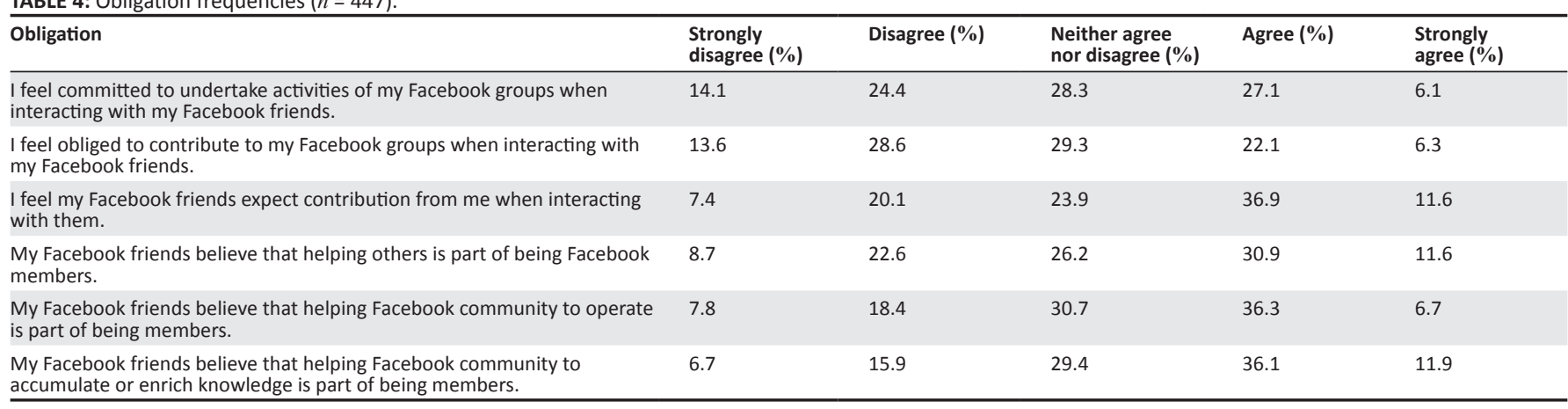


TABLE 5: Knowledge sharing frequencies $(n=447)$.

\begin{tabular}{|c|c|c|c|c|c|}
\hline Knowledge sharing & $\begin{array}{l}\text { Strongly } \\
\text { disagree }(\%)\end{array}$ & Disagree $(\%)$ & $\begin{array}{l}\text { Neither agree } \\
\text { nor disagree }(\%)\end{array}$ & Agree $(\%)$ & $\begin{array}{l}\text { Strongly } \\
\text { agree }(\%)\end{array}$ \\
\hline I enjoy sharing knowledge with my Facebook friends. & 4.7 & 8.3 & 17.0 & 38 & 31.8 \\
\hline $\begin{array}{l}\text { It seems to me that my Facebook friends enjoy sharing their knowledge } \\
\text { with others. }\end{array}$ & 1.8 & 5.4 & 14.8 & 48.3 & 29.8 \\
\hline $\begin{array}{l}\text { It seems to me that Facebook facilitates sharing knowledge among } \\
\text { people. }\end{array}$ & 2.2 & 7.6 & 19.1 & 48.9 & 22.2 \\
\hline $\begin{array}{l}\text { It seems to me that my Facebook friends share the best knowledge that } \\
\text { they have. }\end{array}$ & 7 & 17.3 & 26.7 & 34.1 & 15 \\
\hline $\begin{array}{l}\text { I come to my Facebook community to share knowledge I know about a } \\
\text { particular subject. }\end{array}$ & 7.4 & 18.1 & 29.3 & 34.5 & 10.7 \\
\hline I come to my Facebook community to share my skills. & 10.1 & 25.7 & 33.3 & 20.8 & 10.1 \\
\hline
\end{tabular}

TABLE 6: Correlations.

\begin{tabular}{llll}
\hline Variables & $\mathbf{1}$ & $\mathbf{2}$ & $\mathbf{3}$ \\
\hline 1. Habit & 1.00 & - & - \\
2. Knowledge sharing & $0.297^{* *}$ & 1.00 & - \\
3. Obligation & $0.246^{* *}$ & $0.534^{* *}$ & - \\
4. Facebook usage & $0.455^{* *}$ & $0.157^{* *}$ & - \\
\hline
\end{tabular}

*, correlation is significant at the 0.05 level (two-tailed); **, correlation is significant at the 0.01 level (two-tailed).

columns). Moreover, $36.3 \%$ compared with $18.4 \%$ (Row 7, agree vs. disagree columns) of the respondents believe that helping the Facebook community to operate is a strong indication of being a Facebook community member.

Descriptive statistics scores in Table 5 clearly indicate that the majority of students utilise Facebook for knowledge sharing purposes as opposed to habit and feeling obligated to do so. In light of this finding, as indicated earlier, knowledge sharing is an outcome of social interaction among peers and Facebook provides such a platform as observed in the descriptive statistics scores. Social interaction provides many learning opportunities, for example, when students interact with each other, they are able to exchange ideas and knowledge, and they are able to analyse a certain situation from different perspectives. Students with a certain self-regulation capacity can benefit from the interaction with peers by obtaining feedback and thus improving their performance.

Results from Table 6 indicate the significance levels among four variables measured in this study. Pearson's correlation coefficient was used to establish the significance levels.

The results in Table 6 indicate that Facebook usage is positively correlated to habit with a Pearson's correlation coefficient of $r=0.455$, and the significance level is less than 0.001 as noted by the double asterisk after the coefficient. This implies that the probability of acquiring a correlation coefficient this large in a sample of 447 people if the study had a true null hypothesis (e.g. there is no association between habit and Facebook usage among the youth), is very low and close to zero. In this instance, the researchers have the confidence to conclude that there is a significant positive correlation between Facebook usage and habit. The output from Table 6 further indicates that knowledge sharing is significantly and positively correlated to Facebook usage, $r=0.157$ and also significant with $p<0.001$. Finally, obligation is also positively related to Facebook usage, $r=0.103$ and also significant with $p<0.05$, as denoted by a single asterisk after the coefficient.
As correlation cannot be used to establish causality, the researchers went a step further to measure the amount of variability in one variable being shared by the other. Thus, the level of Facebook usage differs from one person to the other because of a number of factors, not only limited to knowledge sharing, obligation and habit. To measure this variability, $R^{2}$ or the coefficient of determination was used (Field 2013). To demonstrate these results, the independent and dependent variables with the largest correlation were selected (habit and Facebook usage $r=0.445)$. Resultantly, their $R^{2}$ is $(r=0.445)^{2}=$ 0.198 or $19.8 \%$. This value $(19.8 \%)$ explains how much of the variability in Facebook usage is shared by habit among the youth. Although habit was highly correlated to Facebook usage, it can only account for $19.8 \%$ variation in Facebook usage scores. This leaves $80.2 \%$ of the variability to be accounted for by other variables, not limited to knowledge sharing and obligation. However, it is important for the reader to take into consideration that although habit can account for $19.8 \%$ of the variation in Facebook usage among the youth, habit does not necessarily cause this variation.

\section{Contribution}

First, the contribution of this study lies in the finding that habit, obligation and knowledge sharing are correlated significantly and positively to Facebook usage. In addition, this study provides evidence that habitual social media usage among the youth is highly positively correlated to Facebook usage, in contrast to knowledge sharing and obligation. Generally, a person would expect to have a high positive correlation between knowledge sharing and Facebook usage. The thinking here is that the youth spend a significant amount of time interacting on Facebook for the purposes of gaining knowledge to enhance their understanding of life and academic aspects.

\section{Implications for theory}

Literature, as well as primary findings from this study, demonstrates that rural South African youth may be utilising social media platforms mainly for socialising purposes, 
leading to some becoming addicted and others feeling obligated to participate in Facebook activities. There is a great need to reinforce the concept of knowledge sharing or acquisition among the youth. Educators strongly need to redesign their curriculums and incorporate social media in the teaching delivery from an early stage, such as primary education. This, to a large extent, will communicate that formal and informal learning does not start and end when the youth leave the classroom. By so doing, the youth will probably accept social media as a knowledge sharing or acquisition platform at an early age and nurture this function as they progress up the 'education ladder'.

\section{Implications for practice}

This article demonstrates how social media usage has become central to the South African youth. As revealed in literature, habitual social media use is a highway full of challenges for the youth, such as getting in the way of their studies. There is a great need to find a way to educate the youth about responsible use of social media. Researchers of this study propose that knowledge sharing should be the central feature in the use of social media, particularly for the youth, as this has the potential to enhance both their academic and social lives. As pointed out earlier, the youth turn to social media use mainly to escape their problems and worries. Parents have a major role to play in efforts aimed at reducing habitual social media use and, at the same time, avoiding having their children feeling obliged to continuously participate in online activities. This can be achieved by providing a harmonious family environment. Every parent wishes their son or daughter to be an outstanding figure in society by excelling in academic and sporting activities. The failure by a child to live up to these expectations is, therefore, a major cause of friction in a family, thereby leading to the child finding comfort in online platforms such as social media, particularly Facebook. This encourages habitual social media use and at the same time prompts the youth to feel obligated to spend more time on social media as a way of paying back those who may have helped (through counselling or giving attention) them online in times of need.

No matter how much children have fallen short of their parents' or society's expectations, they should be consistently encouraged by the same society they live in. Immediate family should be on the forefront in identifying innovative learning methods that are aligned to the child's and family's goals. Upon realising how supportive the family and society are, regardless of the child's circumstances, the child is more likely to rely on other more traditional methods for support and comfort, thereby limiting the child's participation in online activities. In South Africa, a child does not only belong to the biological parents but also to the community as a whole. It is, therefore, the responsibility of the community to ensure that every child is morally and ethically upright, a concept well known to the locals as 'ubuntu'. Ubuntu is an isiXhosa and isiZulu term which translates to 'I am because we are' (Bidwell 2016:52). In addition, the youth should be encouraged to participate in offline social activities.
These include various outdoor activities popular to each community, for example, playing soccer, rugby, cricket and boxing, which are the more popular sports among the youth in South Africa. There are also a number of indigenous games which parents should encourage their youth to take part. For example, common indigenous games include, dibeke (a running ball game), diketo (a coordination game), kgati (a rope jumping game) and ncuva (a board game) (City of Johannesburg 2010). In different communities, these games are given different names and they accommodate youth of varying ages. It is important to highlight to the youth that these outdoor, offline, social activities offer recognition and companionship, which they equally gain through online platforms except that the experience is different.

\section{Conclusion}

This study concludes that there is a significant positive correlation between Facebook usage and habit among the youth. Although a significant positive relationship exists in all three independent variables, with the dependent variable, frequent visits on Facebook by the youth are more likely to be an effect of habit. Contrary to general expectations, knowledge sharing also has a significant effect on Facebook usage; however, this is low when compared with the effect of habit. Obligation scores have the lowest significant positive correlation with Facebook usage, compared with habit and knowledge sharing, respectively. Thus, obligation has little effect on Facebook usage by the youth.

\section{Limitations}

Data were collected from a single province, but South Africa has nine provinces and the views of the youth residing in these other provinces were not represented in this study. Although the sample was large enough to compensate for this shortcoming, the reader should exercise caution in generalising these findings to the entire country.

\section{Future research}

Further research can be undertaken making use of web surveys that have a potential to go beyond geographical limitations for the purposes of improving on the findings of this study. Furthermore, a qualitative study can be undertaken to gather more information that will reveal deeper insights into habitual social media usage, obligations and social media, as well as knowledge sharing in social media by the youth.

\section{Acknowledgements}

The authors acknowledge support from the Govan Mbeki Research \& Development Centre (GMRDC) at the University of Fort Hare in South Africa.

\section{Competing interests}

The authors duly declare that they have no competing interest that may have inappropriately influenced them in writing this article. 


\section{Author(s) contributions}

H.S. conceptualised and designed the study, supervised the data collection process, analysed and interpreted the data, and wrote most of the manuscript. W.T.C. co-supervised the data collection process, advised on literature content and was also involved in the writing of the manuscript.

\section{References}

Ainin, S., Naqshbandi, M.M., Moghavvemi, S. \& Jaafar, N.I., 2015, 'Facebook usage, socialization and academic performance', Computers \& Education 83, 64-73. https://doi.org/10.1016/j.compedu.2014.12.018

Avis, W.R., 2015, 'Mobile phone and social media interventions for youth development outcomes', viewed 30 September 2016, from http://www.gsdrc.org/wp-content/ uploads/2016/01/HDQ1317.pdf

Bandura, A., 1979, Social learning theory, Prentice Hall, Englewood Cliffs, NJ.

Bidwell, N.J., 2016, 'Moving the centre to design social media in rural Africa', Al \& Society 31(1), 51-77. https://doi.org/10.1007/s00146-014-0564-5

BusinessTech, 2015, 'Facebook reveals user numbers for South Africa', viewed 30 September 2016, from www.businesstech.co.za/news/internet/98085/facebookreveals-user-numbers-for-south-africa/

Caplan, S.E., 2002, 'Problematic Internet use and psychosocial well-being: Development of a theory-based cognitive-behavioral measurement instrument', Computers in Human Behavior 18(5), 553-575. https://doi.org/10.1016/S0747Computers in Humar
5632(02)00004-3

Chew, E.I., LaRose, R., Steinfield, C. \& Velasquez, A., 2011, 'The use of online social networking by rural youth and its effects on community attachment', Information networking by rural youth and its effects on community attachment', Information,
Communication \& Society 14(5), 726-747. https://doi.org/10.1080/136911 Communication
$8 X .2010 .539243$

Chinyamurindi, W.T. \& Louw, G.J., 2010, 'Gender differences in technology acceptance in selected South African companies: Implications for electronic learning', South African Journal of Human Resource Management 8(1), 1-7. https://doi. African Journal of Human
org/10.4102/sajhrm.v8i1.204

City of Johannesburg, 2010, 'Indigenous games played', viewed 06 October 2017 from https://joburg.org.za/index.php?option=com_content\&id=5709:indigenous

Clark, J., 2013, 'South Africa's two economies', Moneyweb, viewed 03 October 2017 from https://www.moneyweb.co.za/archive/south-africas-two-economies/

Creswell, J.W., 2014, Research design: Qualitative, quantitative, and mixed methods approaches, 4th edn., Sage, Thousand Oaks, CA.

Dalvit, L. \& Strelitz, L., 2013, 'Media and mobile phone usage in a South Africa rural area: A baseline study', in J. Freeman (ed.), Proceedings of the Emerging Issues in Communication Research and Policy Conference - Referred Papers, News and Media Research Centre, University of Canberra, Canberra, November 18-19, 2013, pp. 70-80.

DeAndrea, D., Ellison, N.B., LaRose, R., Steinfield, C. \& Fiore, A., 2012, 'Serious social media: On the use of social media for improving students' adjustment to college', Internet and Higher Education 15, 15-23. https://doi.org/10.1016/j.iheduc. 2011.05.009

Development Monitor, 2012, Rural infrastructure in Africa: Unlocking the African moment, Development Support Monitor Paper Series Number 1.

Field, A., 2013, Discovering statistics using SPSS, 4th edn., Sage, Thousand Oaks, CA.

Gwilliam, K., 2011, Africa's transport infrastructure, mainstreaming maintenance and management, World Bank, Washington, DC.

Homans, G.C., 1958, 'Social behaviour exchange', American Journal of Sociology 63(6), 597-606. https://doi.org/10.1086/222355

Huang, H., 2014, Social media generation in Urban China: A study of social media use and addiction among adolescents, Springer-Verlag, Berlin, Heidelberg.

Johnson, D.L., Pejovic, V., Belding, E.M. \& Van Stam, G., 2011, 'Traffic characterization and internet usage in rural Africa', in Proceedings of the 20th International Conference Companion on World Wide Web, Hyderabad, India, March 28-April 01, 2011, pp. 493-502.

Junco, R., 2012, 'Too much face and not enough books: The relationship between multiple indices of Facebook use and academic performance', Computers in Human Behavior 28(1), 187-198. https://doi.org/10.1016/j.chb.2011.08.026

Kankanhalli, A., Tan, B.C.Y. \& Wei, K.K., 2005, 'Contributing knowledge to electronic knowledge repositories: An empirical investigation', MIS Quarterly 29(1), 113-143.

Kim, Y., Sohn, D. \& Choi, S.M., 2011, 'Cultural differences in motivations for using social network sites: A comparative study of American and Korean College students', Computers in Human Behaviour 27(1), 365-372. https://doi. org/10.1016/j.chb.2010.08.015

Kirschner, P.A. \& Karpinski, A.C., 2010, 'Facebook and academic performance', Computers in Human Behaviour 26(6), 1237-1245. https://doi.org/10.1016/j. chb.2010.03.024

Kolek, E.A. \& Saunders, D., 2008, 'Online disclosure: An empirical examination of undergraduate Facebook profiles', NASPA Journal 45(1), 1-25. https://doi. org/10.2202/0027-6014.1905
LaRose, R., 2010, 'The problem of media habits', Communication Theory 20(2), 194-222. https://doi.org/10.1111/j.1468-2885.2010.01360.x

Leung, L., 2007, 'Unwillingness-to-communicate and college students' motives in SMS mobile messaging', Telematics and Informatics 24(2), 115-129. https://doi. org/10.1016/j.tele.2006.01.002

Lewin, C., 2011, Understanding and describing quantitative data', in B. Somekh \& C Lewin (eds.), Theory and methods in social research, 2nd edn., pp. 220-230, Sage, Los Angeles, CA.

Lilley, S., Grodzinsky, F.S. \& Gumbus, A., 2012, 'Revealing the commercialized and complaint Facebook user', Journal of Information Communication and Ethics in Society 10(2), 82-92. https://doi.org/10.1108/14779961211226994

Mackey, A., 2016, 'Sticky emotional connections: Young people, social media, and the re-orientation of affect', Safundi: The Journal of South African and American Studies, viewed 30 September 2016, from http://www.tandfonline.com/doi/full/ 10.1080/17533171.2016.1176398

Morahan-Martin, J., 2008, 'Internet abuse: Emerging trends and lingering questions', in A. Barack (ed.), Psychological aspects of cyberspace: Theory, research, applications, pp. 32-69, Cambridge University Press, New York. https://doi org/10.1017/CBO9780511813740.004

$\mathrm{Ng}, \mathrm{M} ., 2016$, 'Factors influencing the consumer adoption of Facebook: A two-country study of youth markets', Computers in Human Behaviour 54, 491-500. https://doi. org/10.1016/j.chb.2015.08.024

Nkosana, T., Skinner, J. \& Goodier, C., 2016, 'Challenges of ICT adoption and utilisation in small restaurants: A case study of the KwaZulu-Natal Midlands', African Journa of Hospitality, Tourism \& Leisure 5(4), 1-11.

North, D., Johnston, K. \& Ophoff, J., 2014, 'The use of mobile phones by South African university students', Issues in Informing Science and Information Technology 11, 115-138. https://doi.org/10.28945/1984

Pasek, J., More, E. \& Hargittai, E., 2009, 'Facebook and academic performance: Reconciling a media sensation with data', First Monday 14(5), viewed 30 September 2016, from http://www.uic.edu/htbin/cgiwrap/bin/ojs/index.php/ $\mathrm{fm} /$ article/view/2498/2181

Pew Research Center, 2012, 'Teens, social media and privacy', viewed 30 September 2016 , from http://www.pewinternet.org/files/2013/05/PIP_TeensSocialMediaandPrivacy PDF.pdf

Roux, K. \& Dalvit, L., 2014, 'Mobile women: Investigating the digital gender divide in cell phone use in a South African rural area', in Proceedings of the e-Skills for Knowledge Production and Innovation Conference 2014, Cape Town, South Africa, November 17-21, Informing Science Institute, pp. 401-416.

Shava, H., Chinyamurindi, W. \& Somdyala, A., 2016, 'An investigation into the usage of mobile phones among technical and vocational educational and training students in South Africa', South African Journal of Information Management 18(1), a716. https://doi.org/10.4102/sajim.v18i1.716

Smith, C., 2014, 'How many people use 600+ of the top social media, apps, and digital services?', Digital Marketing Ramblings, November, viewed 30 September 2016, from http://expandedramblings.com/index.php/resource-how-many-peopleuse-the-top-social-media/

SouthAfrica.info, 2013, Social media 'integral' to SA students' lives November 12, viewed 30 September 2016, from http://www.southafrica.info/about/media/ social-media-121113.htm\#.VOMFH5F97IX

South Africa Press Association, 2015, 'South Africa: Eskom announces rolling blackouts', All Africa, viewed 02 October 2017, from http://allafrica.com/ stories/201501091340.html

Steenson, M. \& Donner, J., 2009, 'Beyond the personal and the private: Modes of mobile phone sharing in urban India', in S.W. Campbell \& R. Ling (eds.), Mobile communication research annual, vol. 1, pp. 23-250, Transaction Books, communication
Piscataway, NJ.

Vishwanath, A., 2015, 'Habitual Facebook use and its impact on getting deceived on social media', Journal of Computer-Mediated Communication 20, 83-98. https:// doi.org/10.1111/jcc4.12100

Wasko, M. \& Faraj, S., 2000, 'It is what one does: Why people participate and help others in electronic communities of practice', Journal of Strategic Information Systems 9(2/3), 155-173. https://doi.org/10.1016/S0963-8687(00)00045-7

Wiid, J. \& Diggines, C., 2015, Marketing research, 3rd edn., Juta, Cape Town.

World Wide Worx, 2015, Facebook bridges SA gender divide: Internet research, Market Research, viewed 30 September 2016, from http://www.worldwideworx. com/facebook/

World Wide Worx \& Student Brands, 2013, Social media 2013: Addiction and boon to students, Market Research, viewed 20 December 2016, from http://www. worldwideworx.com/hightech-students/

Wyche, S. \& Baumer, E.P.S., 2016, 'Imagined Facebook: An exploratory study of nonusers' perceptions of social media in rural Zambia', New Media \& Society 19(7), users.

Wyche, S.P., Schoenebeck, S.Y. \& Forte, A., 2013, "Facebook is a luxury": An exploratory study of social media use in rural Kenya', in Proceedings of ACM Conference on Computer Supported Cooperative Work and Social Computing (CSCW'13), San Antonio, TX, February 23-27, Association for Computing (CSCW'13), San Antonio, TX, February 23-27, Association
Machinery (ACM). https://doi.org/10.1145/2441776.2441783

Young, K.S., 1998, 'Internet addiction: The emergence of a new clinical disorder', Cyber Psychology \& Behaviour 1(3), 237-244. https://doi.org/10.1089/ cpb.1998.1.237

Zikmund, W.G. \& Babin, B.J., 2010, Essentials of marketing research, 9th edn., South-Western Cengage Learning, Mason, IA. 